\title{
TINGKAT KETERAMPILAN PENGAMBILAN KEPUTUSAN \\ MAHASISWA PENDIDIKAN GURU SEKOLAH DASAR UNIVERSITAS KUNINGAN
}

\section{DECISION-MAKING SKILL OF PRIMARY EDUCATION STUDENT AT UNIVERSITY OF KUNINGAN}

\author{
Myrna Apriany Lestari \\ Pendidikan Guru Sekolah Dasar Universitas Kuningan \\ myrna@uniku.ac.id
}
Pengutipan: Lestari, M. A. (2019). Tingkat keterampilan pengambilan keputusan mahasiswa Pendidikan Guru Sekolah Dasar Universitas Kuningan. Pedagogi: Jurnal Penelitian Pendidikan, 6(2), 39-50.

Diajukan: 11-12-2019Ｄiterima: 30-12-2019Ｄiterbitkan: 31-12-2019

\begin{abstract}
ABSTRAK
Kesalahan individu dalam mengambil keputusan dapat memberikan dampak yang sangat besar dalam kehidupannya karena resiko yang muncul setelahnya. Begitupun yang dialami oleh mahasiswa yang sedang menempuh masa studi di Perguruan Tinggi. Meskipun secara usia, mahasiwa adalah individu yang telah memasuki usia dewasa namun tidak sedikit dari mahasiswa yang mengalami kesulitan dalam menyelesaikan masa studi yang telah ditentukan karena kurangnya keterampilan dalam mengambil keputusan, seperti kesulitan yang dialami mahasiswa di awal masa perkuliahan karena program studi tidak sesuai dengan keinginan pribadinya; atau terganggunya masa studi mahasiswa di tingkat 2 karena kesalahan menentukan prioritas antara perkuliahan dengan kegiatan organisasi; dan kesulitan mahasiswa di tingkat akhir untuk menyelesaikan studi di antara tanggung jawab pekerjaan atau mengurus keluarga baru. Penelitian ini adalah penelitian survey yang dilakukan kepada 240 mahasiswa Prodi Pendidikan Guru Sekolah Dasar (PGSD) Universitas Kuningan Angkatan 2016-2019, 240 mahasiswa ini merupakan sampel penelitian yang dipilih secara random dari total 474 mahasiswa PGSD yang terdaftar. Berdasarkan hasil penelitian yang diperoleh maka dapat disimpulkan bahwa secara umum keterampilan mahasiswa PGSD angkatan 2016-2019 Mayoritas keterampilan pengampilan keputusan mahasiwa PGSD angkatan 2016-2019 telah mencapai kategori yang tinggi meskipun ada beberapa indikator yang masih berada pada kategori sedang, rendah dan rendah sekali. Indikator-indikator tersebut merupakan bagian dari keterampilan menghitung segala aspek pilihan dan keterampilan menghindari jebakan pilihan. Sehingga dibutuhkan sebuah program rencana bantuan pengembangan keterampilan pengambilan keputusan yang diarahkan pada dua keterampilan tersebut.
\end{abstract}

Kata Kunci: keterampilan pengambilan keputusan; mahasiswa PGSD

\section{ABSTRACT}

Individual errors in decision-making can provide a tremendous impact on his life because of the risks that come after. Likewise, experienced by students who are studying in the study period. Based on age status, undergraduate students are individuals who have entered 
adulthood but not at least by quantity of students who have difficulty in completing the study period due to the lack of skills in making decisions, such as the difficulties experienced by beginner's students because the course is not in accordance with the wishes personal; or disruption of a student's study period at level 2 because of an error to set priorities between lectures with activities on the organization; and difficulty level higher's students to complete the study by responsibilities of the job or taking care of the new family. The research design was a survey conducted to 240 undergraduate students in the Department of Elementary Teacher Education, the University of Kuningan on Academic Year 2016 until 2019, 240 students of a study sample by randomly selected from a total of 474 students enrolled. Based on the results obtained, it can be concluded that in general, the student's decision-making skills by the majority have reached a high category although there are some indicators that still are in the category of the medium, low, and very low. These indicators are part of the skills of counting all aspects of selection and skill to avoid the trap of choice. Then, we need a program of decision-making skills development plan aimed at both skills.

Keywords: decision-making skills; undergraduate student in elementary teacher education

\section{PENDAHULUAN}

Universitas Kuningan telah menetapkan visi untuk menjadi Universitas Unggul yang memiliki komitmen tinggi terhadap pemberdayaan masayarakat pada tahun 2032. Keunggulan dan komitmen UNIKU ini dapat ditandai dengan beberapa hal seperti diperolehnya indeks prestasi kumulatif (IPK) mahasiswa yang tinggi, ketepatan penyelesaikan studimahasiswa, serta prestasi yang membanggakan diberbaga ibidang. Untuk mencapai hal tersebut, perlu langkah-langkah strategis yang dilakukan dengan memberikan sistem pelayanan prima kepada mahasiswa termasuk dalam membantu mahasiswa menghadapi berbagai tantangan, hambatan dan rintangan yang ditemui saat menempuh masa studi.

Tidak sedikit dari mahasiswa yang gagal menyelesaikan masa studinya karena berbagai macam kendala yang sebetulnya dapat ditanggulangi bila mahasiswa tersebut memiliki softskill yang memadai, salah satunya adalah keterampilan pengambilan keputusan. Hal ini dikarenakan individu secara sadar maupun tidak senantiasa dihadapkan pada berbagai macam pilihan dalam hidupnya yang tidak jarang menimbulkan sebuah konflik, ketidakmampuan individu dalam mengambil keputusan yang tepatakan berdampak pada kehidupannya secara keseluruhan karena setiap pilihan memiliki resiko yang harus dipertanggungjawabkan. Untuk meminimalisir kondisi di atas, maka penelitian tentang keterampilan pengambilan keputusan mahasiswa harus dilakukan agar program pengembangan softskill mahasiswa dapat disusun berdasarkan kebutuhan yang benar-benar dirasakan oleh mahasiswa.

Penelitian ini bertujuan untuk mengetahui tingkat keterampilan pengambilan keputusan mahasiswa pada Program Studi Pendidikan Guru Sekolah Dasar Universitas Kuningan.

Pengambilan keputusan adalah hal yang tidak dapat dipisahkan dari kehidupan manusia. Setiap waktu individu melakukan proses memilih untuk mengambil keputusan, mulai dari memilih hal-hal yang sederhana hingga pilihan hidup yang memiliki dampak besar bagi kehidupannya. Penggunaan istilah pengambilan keputusan (Decision Making) biasanya identik dengan sebuah kepemimpinan atau kegiatan manajerial dalam suatu kelompok dan organisasi, namun bila dipikirkan secara lebih mendalam sebenarnya setiap orang adalah pemimpin yang harus mengambil keputusan bagi dirinya sendiri dan hidupnya. George R. Terry, Sondang P. Siagian, James A. F. Stoner (Akhmad Sudrajat, 2010) memaparkan pengertian pengambilan keputusan adalah pemilihan alternatif perilaku (kelakuan) tertentu dari dua atau lebih alternatif yang ada berdasarkan suatu pendekatan yang sistematis terhadap 
hakikat alternatif yang dihadapi dan mengambil tindakan yang menurut perhitungan untuk memilih suatu tindakan sebagai cara pemecahan masalah.

Menurut Wardani (2010) menyebutkan beberapa keterampilan pengambilan keputusan yaitu: (1) Kemampuan mengidentifikasi dasar penggerak dalam memilih; (2) Kemampuan menggunakan alat penimbang dalam memilih; (3) Kemampuan menggunakan bahan pertimbangan dalam memilih; (4) Kemampuan menghitung segala aspek pilihan; (5)Kemampuan memanajemen penentuan pilihan; (6) Kemampuan menghindari jebakanjebakan dalam memilih; (7) Memiliki strategi menangani kesalahan dalam memilih. Keterampilan-keterampilan pengambilan keputusan tersebut telah ada dalam diri setiap individu hanya terkadang tidak disadari dan kurang terlatih sehingga kurang berkembangan. Hal ini yang sering kali menyebabkan individu kurang tepat dalam mengambil keputusan atau mengambil keputusan yang tidak optimal bagi dirinya. Oleh sebab itu, di lingkungan sekolah konselor atau guru BK perlu menyusun rencana bantuan bagi setiap siswa agar dapat mengembangkan keterampilannya dalam pengambilan keputusan sehingga siswa dapat mengambil keputusan yang tepat dan optimal baik bagi dirinya sendiri maupun bagi masa depan dan lingkungan sekitarnya.

\section{METODE PENELITIAN}

Penelitian ini menggunakan penelitian survey untuk melihat gambaran umum keterampilan pengambilan keputusan mahasiswa PGSD angkatan tahun 2016-2019. Tujuan penelitian survey adalah untuk memberikan gambaran secara mendetail tentang latar belakang, sifat-sifat, serta karakter-karakter yang khas dari kasus atau kejadian suatu hal yang bersifat umum. Dan metode yang digunakan dalam penelitian ini adalah metode deskritif. Metode ini dilakukan untuk melakukan pengukuran terhadap fenomena sosial tertentu, kemudian dijelaskan secara deskriptif atau naratif. Dalam penelitian ini, peneliti mencoba mendeskripsikan tentang keterampilan pengambilan keputusan mahasiswa PGSD.

Pada penelitian ini, populasinya adalah mahasiswa PGSD Universitas Kuningan Angkatan 2016-2019. Sedangkan sampel penelitian ini adalah sebanyak 220 orang mahasiswa karena jumlah mahasiswa PGSD Universitas Kuningan Angkatan 2016-2019 kurang lebih 474 orang.

Pemilihan angket sebagai alat pengumpul data dalam penelitian ini didasarkan pada pendapat Sugiyono yang menyatakan bahwa, angket merupakan teknik pengumpul data yang efisien bila peneliti tahu dengan pasti variabel yang akan diukur dan tahu apa yang bisa diharapkan dari responden. Lebih lanjut angket juga cocok digunakan bila jumlah responden cukup besar dan tersebar di wilayah yang luas.

Instrumen penelitian yang digunakan dalam memperoleh data keterampilan pengambilan keputusan mahasiswa ini berbentuk angket dengan nilai 1 untuk jawaban "Ya" dan nilai 0 untuk jawaban "Tidak". Lalu instrumen ini di uji validitasnya secara logis melalui validasi isi dan konstruk. Validasi logis yaitu mencakup validasi isi pernyataan/pertanyaan yang ditentukan atas dasar pertimbangan (expert judgment) dari para ahli dan validitas konstruk berorientasi pada pemeriksaan butir instrumen guna menetapkan apakah butir-butir tersebut cocok untuk menaksirkan unsur-unsur konstruk variabel.

\section{HASIL PENELITIAN DAN PEMBAHASAN}

Penelitian ini merupakan penelitian survey yang dilakukan kepada 240 mahasiswa Prodi Pendidikan Guru Sekolah Dasar (PGSD) Universitas Kuningan Angkatan 2016-2019, 240 mahasiswa ini merupakan sampel penelitian yang dipilih secara random dari total 474 mahasiswa PGSD yang terdaftar. 
Setiap sampel diminta untuk mengisi angket yang telah divalidasi secara konstruk untuk melihat kesesuaian antara indikator capaian dan pernyataan yang disajikan. Berdasarkan hasil pengolahan data, diperoleh gambaran umum keterampilan pengambilan keputusan mahasiswa PGSD Angkatan 2016-2019, sebagai berikut.

Tabel 1. Persentase Keterampilan Pengambilan Keputusan

Mahasiswa PGSD Angkatan 2016

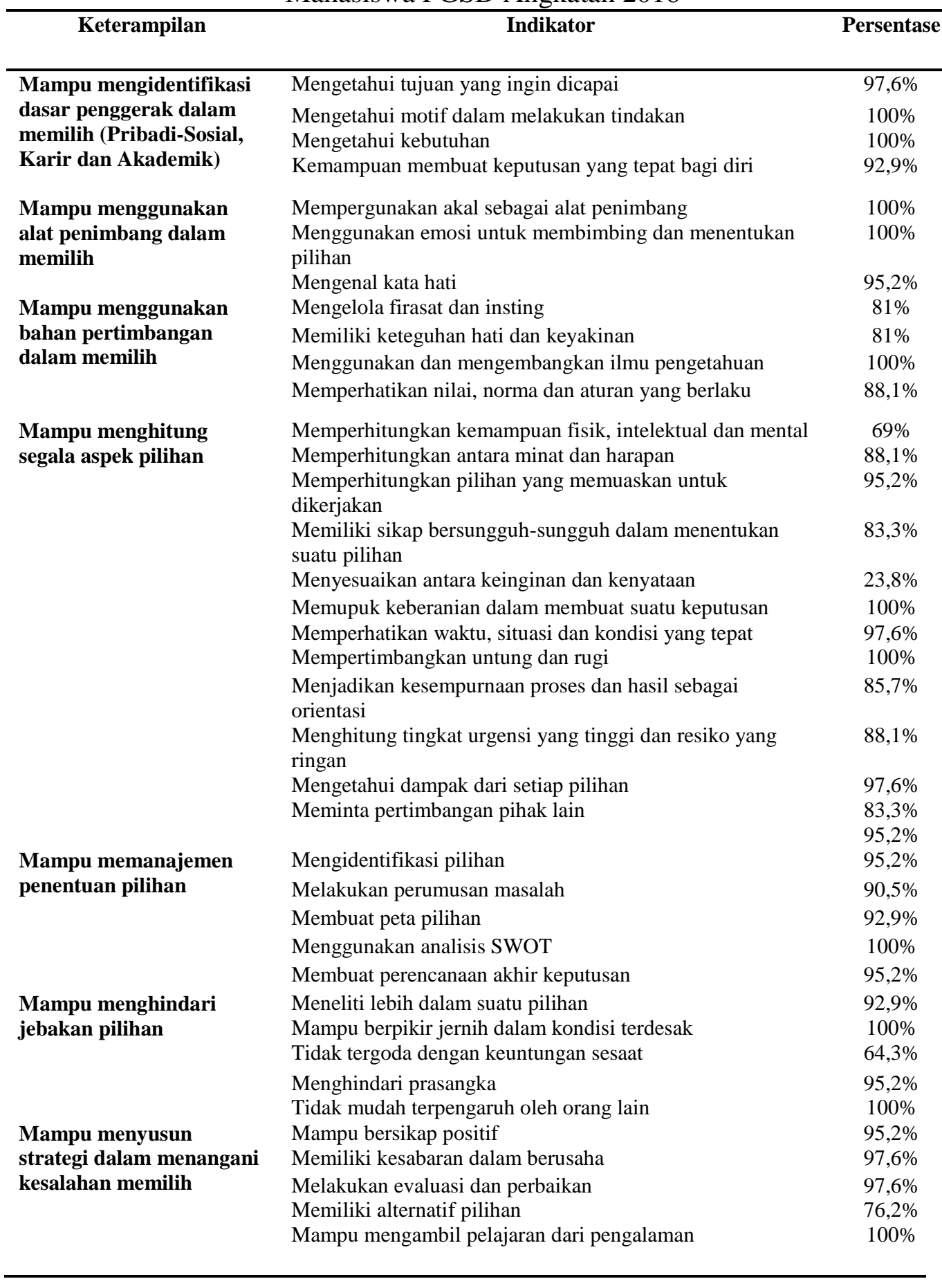

Tabel 1 di atas menggambarkan keterampilan pengambilan keputusan Mahasiswa PGSD Angkatan 2016 per indikator dari tujuh keterampilan yang diukur. Secara umum, keterampilan pengambilan keputusan Mahasiwa PGSD Angkatan 2016 sudah berada pada 
kategori tinggi, hal ini terlihat dari presentase yang dicapai pada setiap indikatornya namun ada beberapa indikator yang masih berada pada kategori sedang bahkan rendah sekali.

Indikator yang masih berada pada kategori sedang adalah indikator yang menunjukkan kemampuan untuk memperhitungkan kemampuan fisik, intelektual dan mental serta indikator yang menunjukkan kemampuan untuk tidak tergoda dengan keuntungan sesaat. Sedangkan indikator yang berada pada kategori rendah sekali adalah indikator yang menunjukkan kemampuan menyesuaikan antara keinginan dan kenyataan. Pada tabel berikutnya akan disajikan presentase keterampilan pengambilan keputusan mahasiswa PGSD angkatan 2017.

Tabel 2. Persentase Keterampilan Pengambilan Keputusan

Mahasiswa PGSD Angkatan 2017

\begin{tabular}{|c|c|c|}
\hline Keterampilan & Indikator & Presentase \\
\hline \multirow{5}{*}{$\begin{array}{l}\text { Mampu mengidentifikasi } \\
\text { dasar penggerak dalam } \\
\text { memilih (Pribadi-Sosial, } \\
\text { Karir dan Akademik) }\end{array}$} & Mengetahui tujuan yang ingin dicapai & $85,9 \%$ \\
\hline & Mengetahui motif dalam melakukan tindakan & $98,6 \%$ \\
\hline & & $98,6 \%$ \\
\hline & Mengetahui kebutuhan & $98,6 \%$ \\
\hline & Kemampuan membuat keputusan yang tepat bagi diri & $95,8 \%$ \\
\hline \multirow{3}{*}{$\begin{array}{l}\text { Mampu menggunakan } \\
\text { alat penimbang dalam } \\
\text { memilih }\end{array}$} & Mempergunakan akal sebagai alat penimbang & $94,4 \%$ \\
\hline & $\begin{array}{l}\text { Menggunakan emosi untuk membimbing dan menentukan } \\
\text { pilihan }\end{array}$ & $97,2 \%$ \\
\hline & Mengenal kata hati & $84,5 \%$ \\
\hline Mampu menggunakan & Mengelola firasat dan insting & $76,1 \%$ \\
\hline bahan pertimbangan & Memiliki keteguhan hati dan keyakinan & $94,4 \%$ \\
\hline \multirow[t]{2}{*}{ dalam memilih } & Menggunakan dan mengembangkan ilmu pengetahuan & $91,5 \%$ \\
\hline & Memperhatikan nilai, norma dan aturan yang berlaku & $85,9 \%$ \\
\hline \multirow{13}{*}{$\begin{array}{l}\text { Mampu menghitung } \\
\text { segala aspek pilihan }\end{array}$} & Memperhitungkan kemampuan fisik, intelektual dan mental & $71,8 \%$ \\
\hline & Memperhitungkan antara minat dan harapan & $62 \%$ \\
\hline & Memperhitungkan pilihan yang memuaskan untuk dikerjakan & $83,1 \%$ \\
\hline & $\begin{array}{l}\text { Memiliki sikap bersungguh-sungguh dalam menentukan suatu } \\
\text { pilihan }\end{array}$ & $91,5 \%$ \\
\hline & Menyesuaikan antara keinginan dan kenyataan & $28,2 \%$ \\
\hline & Memupuk keberanian dalam membuat suatu keputusan & $97,2 \%$ \\
\hline & Memperhatikan waktu, situasi dan kondisi yang tepat & $98,6 \%$ \\
\hline & Mempertimbangkan untung dan rugi & $98,6 \%$ \\
\hline & Menjadikan kesempurnaan proses dan hasil sebagai orientasi & $91,5 \%$ \\
\hline & & $91,5 \%$ \\
\hline & Menghitung tingkat urgensi yang tinggi dan resiko yang ringan & $85,9 \%$ \\
\hline & Mengetahui dampak dari setiap pilihan & $80,3 \%$ \\
\hline & Meminta pertimbangan pihak lain & $93 \%$ \\
\hline \multirow{5}{*}{$\begin{array}{l}\text { Mampu memanajemen } \\
\text { penentuan pilihan }\end{array}$} & Mengidentifikasi pilihan & $84,5 \%$ \\
\hline & Melakukan perumusan masalah & $88,7 \%$ \\
\hline & Membuat peta pilihan & $80,3 \%$ \\
\hline & Menggunakan analisis SWOT & $88,7 \%$ \\
\hline & Membuat perencanaan akhir keputusan & $94,4 \%$ \\
\hline \multirow{5}{*}{$\begin{array}{l}\text { Mampu menghindari } \\
\text { jebakan pilihan }\end{array}$} & Meneliti lebih dalam suatu pilihan & $91,5 \%$ \\
\hline & Mampu berpikir jernih dalam kondisi terdesak & $90,4 \%$ \\
\hline & Tidak tergoda dengan keuntungan sesaat & $38 \%$ \\
\hline & Menghindari prasangka & $93 \%$ \\
\hline & Tidak mudah terpengaruh oleh orang lain & $95,8 \%$ \\
\hline Mampu menyusun & Mampu bersikap positif & $94,4 \%$ \\
\hline strategi dalam menangani & Memiliki kesabaran dalam berusaha & $90,1 \%$ \\
\hline \multirow[t]{3}{*}{ kesalahan memilih } & Melakukan evaluasi dan perbaikan & $100 \%$ \\
\hline & Memiliki alternatif pilihan & $90,1 \%$ \\
\hline & Mampu mengambil pelajaran dari pengalaman & $98,6 \%$ \\
\hline
\end{tabular}

Tabel 2 menunjukkan bahwa secara umum keterampilan pengambilan keputusan mahasiswa PGSD angkatan 2017 pun rata-rata berada pada kategori yang tinggi di setiap indikatornya namun ada beberapa indikator yang masih berada pada kategori sedang dan rendah. Indikator yang masih berada pada kategori sedang adalah indikator yang 
menunjukkan kemampuan untuk memperhitungkan kemampuan fisik,intelektual dan mental serta kemampuan untuk memperhitungkan antara minat dan harapan.

Sedangkan indikator yang masih berada pada kategori rendah adalah indikator yang menunjukkan kamampuan untuk menyesuaikan antara keinginan dan kenyataan serta kemampuan untuk tidak tergoda dengan keuntungan sesaat. Tabel 4.3 akan menyajikan prensentase tingkat keterampilan pengambilan keputusan mahasiswa PGSD angkatan 2018.

Tabel 3. Persentase Keterampilan Pengambilan Keputusan

Mahasiswa PGSD Angkatan 2018

\begin{tabular}{|c|c|c|}
\hline Keterampilan & Indikator & Persentase \\
\hline \multirow{5}{*}{$\begin{array}{l}\text { Mampu mengidentifikasi } \\
\text { dasar penggerak dalam } \\
\text { memilih(Pribadi-Sosial, } \\
\text { Karir dan Akademik) }\end{array}$} & Mengetahui tujuan yang ingin dicapai & $93,5 \%$ \\
\hline & Mengetahui motif dalam melakukan tindakan & $98,4 \%$ \\
\hline & & $96,8 \%$ \\
\hline & Mengetahui kebutuhan & $88,7 \%$ \\
\hline & Kemampuan membuat keputusan yang tepat bagi diri & $91,9 \%$ \\
\hline \multirow{3}{*}{$\begin{array}{l}\text { Mampu menggunakan } \\
\text { alat penimbang dalam } \\
\text { memilih }\end{array}$} & Mempergunakan akal sebagai alat penimbang & $98,4 \%$ \\
\hline & $\begin{array}{l}\text { Menggunakan emosi untuk membimbing dan menentukan } \\
\text { pilihan }\end{array}$ & $100 \%$ \\
\hline & Mengenal kata hati & $98,4 \%$ \\
\hline \multirow{4}{*}{$\begin{array}{l}\text { Mampu menggunakan } \\
\text { bahan pertimbangan } \\
\text { dalam memilih }\end{array}$} & Mengelola firasat dan insting & $93,5 \%$ \\
\hline & Memiliki keteguhan hati dan keyakinan & $87,1 \%$ \\
\hline & Menggunakan dan mengembangkan ilmu pengetahuan & $91,9 \%$ \\
\hline & Memperhatikan nilai, norma dan aturan yang berlaku & $77,4 \%$ \\
\hline \multirow{13}{*}{$\begin{array}{l}\text { Mampu menghitung } \\
\text { segala aspek pilihan }\end{array}$} & Memperhitungkan kemampuan fisik, intelektual dan mental & $61,3 \%$ \\
\hline & Memperhitungkan antara minat dan harapan & $75,8 \%$ \\
\hline & Memperhitungkan pilihan yang memuaskan untuk dikerjakan & $91,9 \%$ \\
\hline & $\begin{array}{l}\text { Memiliki sikap bersungguh-sungguh dalam menentukan suatu } \\
\text { pilihan }\end{array}$ & $88,7 \%$ \\
\hline & Menyesuaikan antara keinginan dan kenyataan & $38,7 \%$ \\
\hline & Memupuk keberanian dalam membuat suatu keputusan & $93,5 \%$ \\
\hline & Memperhatikan waktu, situasi dan kondisi yang tepat & $96,8 \%$ \\
\hline & Mempertimbangkan untung dan rugi & $96,8 \%$ \\
\hline & Menjadikan kesempurnaan proses dan hasil sebagai orientasi & $88,7 \%$ \\
\hline & & $93,5 \%$ \\
\hline & Menghitung tingkat urgensi yang tinggi dan resiko yang ringan & $93,5 \%$ \\
\hline & Mengetahui dampak dari setiap pilihan & $75,8 \%$ \\
\hline & Meminta pertimbangan pihak lain & $88,7 \%$ \\
\hline \multirow{5}{*}{$\begin{array}{l}\text { Mampu memanajemen } \\
\text { penentuan pilihan }\end{array}$} & Mengidentifikasi pilihan & $88,7 \%$ \\
\hline & Melakukan perumusan masalah & $93,5 \%$ \\
\hline & Membuat peta pilihan & $75,8 \%$ \\
\hline & Menggunakan analisis SWOT & $88,7 \%$ \\
\hline & Membuat perencanaan akhir keputusan & $83,9 \%$ \\
\hline \multirow{5}{*}{$\begin{array}{l}\text { Mampu menghindari } \\
\text { jebakan pilihan }\end{array}$} & Meneliti lebih dalam suatu pilihan & $95,2 \%$ \\
\hline & Mampu berpikir jernih dalam kondisi terdesak & $91,9 \%$ \\
\hline & Tidak tergoda dengan keuntungan sesaat & $69,4 \%$ \\
\hline & Menghindari prasangka & $96,8 \%$ \\
\hline & Tidak mudah terpengaruh oleh orang lain & $96,8 \%$ \\
\hline \multirow{5}{*}{$\begin{array}{l}\text { Mampu menyusun } \\
\text { strategi dalam menangani } \\
\text { kesalahan memilih }\end{array}$} & Mampu bersikap positif & $98,4 \%$ \\
\hline & Memiliki kesabaran dalam berusaha & $91,1 \%$ \\
\hline & Melakukan evaluasi dan perbaikan & $93,5 \%$ \\
\hline & Memiliki alternatif pilihan & $79 \%$ \\
\hline & Mampu mengambil pelajaran dari pengalaman & $95,2 \%$ \\
\hline
\end{tabular}

Berdasarkan Tabel 3, secara umum dapat terlihat bahwa keterampilan pengambilan keputusan mahasiwa PGSD angkatan 2018 pun mayoritas telah berada pada kategori tinggi untuk setiap indikatornya dan hanya beberapa indikator saja yang masih berada dikategori sedang juga rendah. Indikator keterampilan pengambilan keputusan yang masih berada pada kategori sedang yaitu indikator yang menunjukkan kemampuan untuk mengetahui dampak 
dari setiap pilihan, membuat peta pilihan, serta tidak tergoda dengan keuntungan sesaat. Sedangkan indikator yang masih berada pada kategori rendah adalah kemampuan untuk menyesuaikan antara keinginan dan kenyataan. Selanjutnya presentase keterampilan pengambilan keputusan mahasiswa PGSD angkatan 2019 akan disajikan pada tabel 4 berikut.

Tabel 4. Persentase Keterampilan Pengambilan Keputusan

\begin{tabular}{|c|c|c|}
\hline Keterampilan & Indikator & Persentase \\
\hline \multirow{5}{*}{$\begin{array}{l}\text { Mampu mengidentifikasi } \\
\text { dasar penggerak dalam } \\
\text { memilih (Pribadi-Sosial, } \\
\text { Karir dan Akademik) }\end{array}$} & Mengetahui tujuan yang ingin dicapai & $100 \%$ \\
\hline & Mengetahui motif dalam melakukan tindakan & $100 \%$ \\
\hline & & $95,6 \%$ \\
\hline & Mengetahui kebutuhan & $92,6 \%$ \\
\hline & Kemampuan membuat keputusan yang tepat bagi diri & $91,2 \%$ \\
\hline \multirow{3}{*}{$\begin{array}{l}\text { Mampu menggunakan } \\
\text { alat penimbang dalam } \\
\text { memilih }\end{array}$} & Mempergunakan akal sebagai alat penimbang & $95,6 \%$ \\
\hline & Menggunakan emosi untuk membimbing dan menentukan pilihan & $100 \%$ \\
\hline & Mengenal kata hati & $95,6 \%$ \\
\hline \multirow{3}{*}{$\begin{array}{l}\text { Mampu menggunakan } \\
\text { bahan pertimbangan } \\
\text { dalam memilih }\end{array}$} & Mengelola firasat dan insting & $94,1 \%$ \\
\hline & Memiliki keteguhan hati dan keyakinan & $94,1 \%$ \\
\hline & Menggunakan dan mengembangkan ilmu pengetahuan & $88,2 \%$ \\
\hline \multirow{13}{*}{$\begin{array}{l}\text { Mampu menghitung } \\
\text { segala aspek pilihan }\end{array}$} & Memperhatikan nilai, norma dan aturan yang berlaku & $91,2 \%$ \\
\hline & Memperhitungkan kemampuan fisik, intelektual dan mental & $83,8 \%$ \\
\hline & Memperhitungkan antara minat dan harapan & $83,8 \%$ \\
\hline & Memperhitungkan pilihan yang memuaskan untuk dikerjakan & $97,1 \%$ \\
\hline & $\begin{array}{l}\text { Memiliki sikap bersungguh-sungguh dalam menentukan suatu } \\
\text { pilihan }\end{array}$ & $89,7 \%$ \\
\hline & Menyesuaikan antara keinginan dan kenyataan & $20,6 \%$ \\
\hline & Memupuk keberanian dalam membuat suatu keputusan & $95,6 \%$ \\
\hline & Memperhatikan waktu, situasi dan kondisi yang tepat & $100 \%$ \\
\hline & Mempertimbangkan untung dan rugi & $100 \%$ \\
\hline & Menjadikan kesempurnaan proses dan hasil sebagai orientasi & $\begin{array}{l}95,6 \% \\
92,6 \%\end{array}$ \\
\hline & Menghitung tingkat urgensi yang tinggi dan resiko yang ringan & $95,6 \%$ \\
\hline & Mengetahui dampak dari setiap pilihan & $86,8 \%$ \\
\hline & Meminta pertimbangan pihak lain & $98,5 \%$ \\
\hline \multirow{5}{*}{$\begin{array}{l}\text { Mampu memanajemen } \\
\text { penentuan pilihan }\end{array}$} & Mengidentifikasi pilihan & $92,6 \%$ \\
\hline & Melakukan perumusan masalah & $97,1 \%$ \\
\hline & Membuat peta pilihan & $88,2 \%$ \\
\hline & Menggunakan analisis SWOT & $97,1 \%$ \\
\hline & Membuat perencanaan akhir keputusan & $89,7 \%$ \\
\hline \multirow{5}{*}{$\begin{array}{l}\text { Mampu menghindari } \\
\text { jebakan pilihan }\end{array}$} & Meneliti lebih dalam suatu pilihan & $94,1 \%$ \\
\hline & Mampu berpikir jernih dalam kondisi terdesak & $100 \%$ \\
\hline & Tidak tergoda dengan keuntungan sesaat & $75 \%$ \\
\hline & Menghindari prasangka & $100 \%$ \\
\hline & Tidak mudah terpengaruh oleh orang lain & $98,5 \%$ \\
\hline \multirow{5}{*}{$\begin{array}{l}\text { Mampu menyusun } \\
\text { strategi dalam menangani } \\
\text { kesalahan memilih }\end{array}$} & Mampu bersikap positif & $100 \%$ \\
\hline & Memiliki kesabaran dalam berusaha & $97,1 \%$ \\
\hline & Melakukan evaluasi dan perbaikan & $92,6 \%$ \\
\hline & Memiliki alternatif pilihan & $79,4 \%$ \\
\hline & Mampu mengambil pelajaran dari pengalaman & $100 \%$ \\
\hline
\end{tabular}

Berdasarkan Tabel 4 tersebut dapat dilihat secara umum keterampilan pengambilan keputusan mahasiswa PGSD angkatan 2019 pun sudah berada pada kategori tinggi, meskipun masih ada dua indikator yang berada pada kategori sedang dan rendah sekali. Indikator yang masih berada pada kategori sedang adalah indikator yang menunjukkan kemampuan untuk tidak tergoda dengan keuntungan sesaat dan indikator yang masih berada pada kategori rendah sekali adalah indikator yang menunjukkan kemampuan untuk menyesuaikan antara keinginan dan kenyataan. 
Untuk memperoleh gambaran umum yang lebih lengkap maka pada tabel 4.5dan diagram batang berikut ini akan disajikan perbandingan presentase keterampilan pengambilan keputusan mahasiswa PGSD angkatan 2016-2019 pada tujuh aspek keterampilan yang diukur.

Tabel 5. Perbandingan Persentase Keterampilan Pengambilan Keputusan Mahasiswa PGSD Angkatan 2016-2019

\begin{tabular}{lcccc}
\hline \multicolumn{1}{c}{ Keterampilan } & $\begin{array}{c}\text { Angkatan } \\
\mathbf{2 0 1 6}\end{array}$ & $\begin{array}{c}\text { Angkatan } \\
\mathbf{2 0 1 7}\end{array}$ & $\begin{array}{c}\text { Angkatan } \\
\mathbf{2 0 1 8}\end{array}$ & $\begin{array}{c}\text { Angkatan } \\
\mathbf{2 0 1 9}\end{array}$ \\
\hline $\begin{array}{l}\text { Mampu mengidentifikasi dasar penggerak } \\
\text { dalam memilih (Pribadi-Sosial, Karir dan }\end{array}$ & $98,1 \%$ & $95,5 \%$ & $93,9 \%$ & $95,9 \%$ \\
$\begin{array}{l}\text { Akademik) } \\
\text { Mampu menggunakan alat penimbang dalam } \\
\text { memilih }\end{array}$ & $98,4 \%$ & $92 \%$ & $98,9 \%$ & $97,1 \%$ \\
$\begin{array}{l}\text { Mampu menggunakan bahan pertimbangan } \\
\text { dalam memilih }\end{array}$ & $87,5 \%$ & $87 \%$ & $87,5 \%$ & $91,9 \%$ \\
$\begin{array}{l}\text { Mampu menghitung segala aspek pilihan } \\
\text { Mampu memanajemen penentuan pilihan }\end{array}$ & $85,2 \%$ & $82,6 \%$ & $83,4 \%$ & $87,7 \%$ \\
Mampu menghindari jebakan pilihan & $94,8 \%$ & $87,3 \%$ & $86,1 \%$ & $92,9 \%$ \\
$\begin{array}{l}\text { Mampu menyusun strategi dalam menangani } \\
\text { kesalahan memilih }\end{array}$ & $90,5 \%$ & $81,7 \%$ & $90 \%$ & $93,5 \%$ \\
\hline
\end{tabular}

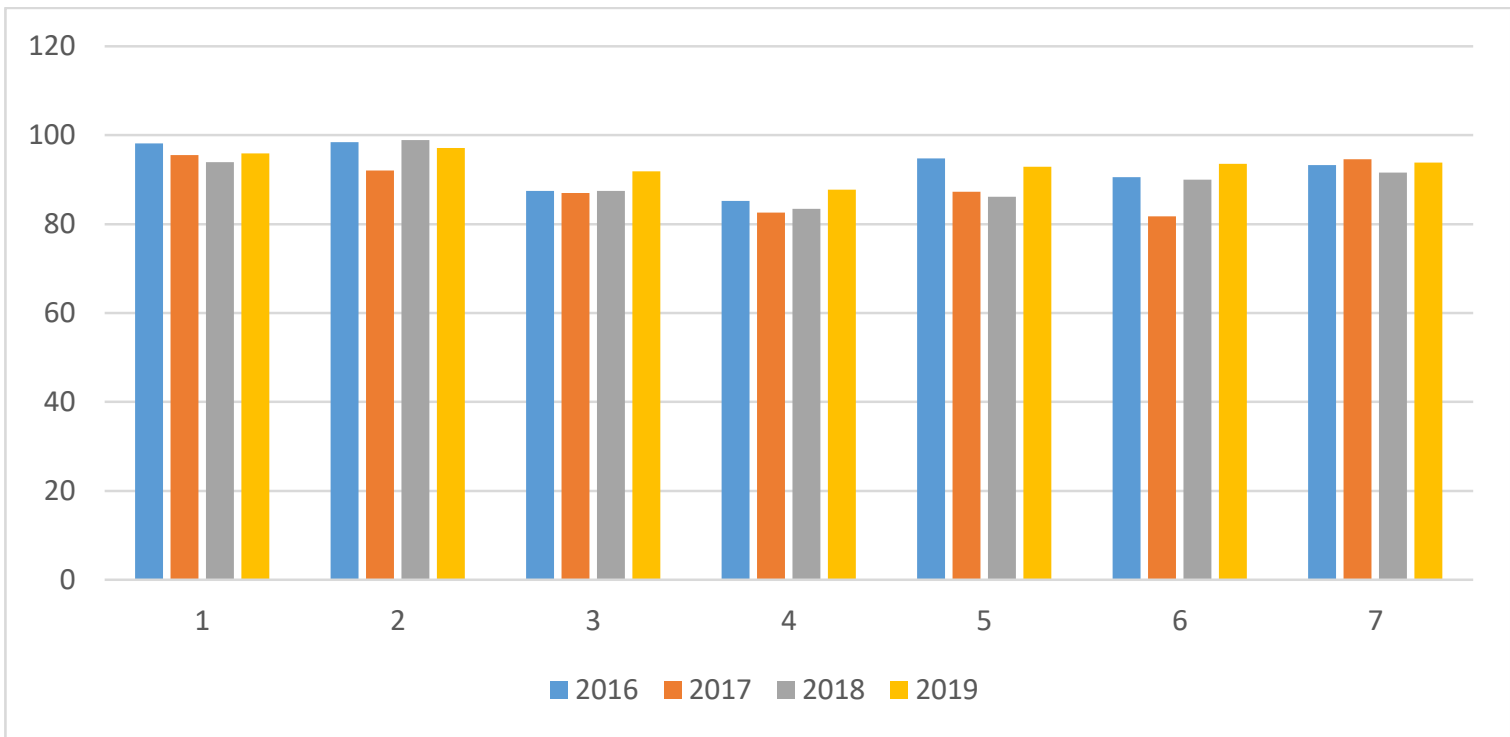

Gambar 1. Perbandingan Persentase Keterampilan Pengambilan Keputusan Mahasiswa PGSD Angkatan 2016-2019

Berdasarkan Tabel 5 dan Gambar 1 di atas dapat dilihat bahwa secara umum keterampilan pengambilan keputusan mahasiswa PGSD angkatan 2016-2019 tidak menunjukkan perbedaan yang terlalu signifikan dan setiap angkatan telah mencapai kategori tinggi pada setiap aspek keterampilan pengambilan keputusan. Hal ini sejalan dengan penelitian sebelumnya yang ditelah dilakukan oleh Isnaeni Wulandari pada tahun 2018 yang berjudul "Perbandingan Tingkat Decision Making Mahasiswa PGSD Universitas Kuningan Berdasarkan Perbedaan Gender" yang menunjukkan bahwa kemampuan pengambilan keputusan mahasiwa PGSD berada pada rata-rata skor 71-81 dan tidak terdapat tidak terdapat 
perbedaan kemampuan decision making yang signifikan antara laki-laki dan perempuan mahasiswa PGSD Universitas Kuningan.

Berdasarkan gambaran umum dapat terlihat bahwa keterampilan pengambilan keputusan mahasiswa PGSD angkatan 2016- 2019 berada pada kategori tinggi meskipun dari angkatan-angkatan tersebut terdapat beberapa indikator yang masih berada pada kategori sedang, rendah dan rendah sekali. Secara umum indikator yang berada pada kategori sedang yaitu indikator yang menunjukkan kemampuan untuk memperhitungkan kemampuan fisik, intelektual dan mental; kemampuan untuk tidak tergoda dengan keuntungan sesaat; kemampuan untuk memperhitungkan antara minat dan harapan; kemampuan untuk mengetahui dampak dari setiap pilihan; dan kemampuan untukmembuat peta pilihan. Sedangkan indikator yang masih berada pada kategori rendah dan rendah sekali adalah indikator yang menunjukkan kamampuan untuk menyesuaikan antara keinginan.

Indikator yang menunjukkan kemampuan untuk memperhitungkan kemampuan fisik, intelektual dan mental; kemampuan untuk memperhitungkan antara minat dan harapan; mengetahui dampak dari setiap pilihan; serta menyesuaikan antara keinginan dan kenyataan adalah bagian dari keterampilan menghitung segala aspek pilihan. Keterampilan ini sangat penting dimiliki karena akan berakibat dan berpengaruh terhadap langkah ke depan, Wardani (2010) memaparkan setiap pilihan individu pilihan harus sesuai dengan kemampuan (fisik, intelektual dan mental); sesuai juga dengan minat, keinginan dan harapan; pilihan yang memuaskan dalam mengerjakannya; sikap bersungguh-sungguh dalam menentukan pilihan tersebut; penyesuaian kehendak diri dengan kondisi realitas yang ada; memupuk keberanian dalam menentukan suatu keputusan; mempertimbangkan peran waktu, situasi, dan kondisi yang tepat dalam menentukan suatu pilihan; mempertimbangkan untung dan rugi dalam suatu pilihan; keputusan yang berorientasi pada kesempurnaan hasil dan proses; memiliki tingkat urgensi yang tinggi dan resiko yang ringan; pilihan yang diketahui dampak-dampaknya; dan meminta pertimbangan Tuhan Yang Maha Esa.

Pada kenyataannya di lapangan, salah satu faktor yang menyebabkan mahasiswa PGSD masih kesulitan mengembangkan keterampilan ini adalah mahasiswa PGSD masih belum memahami minat, keinginan dan harapan yang dimilikinya belum memahami pula kemampuan (fisik, intelektual dan mentalnya), hal ini terlihat dari hasil wawancara penerimaan mahasiswa baru dan dalam diskusi bimbingan karir bahwa mahasiswa memilih prodi PGSD karena rekomendasi orangtua bukan atas dasar pilihan pribadi berdasarkan minat dan bakat yang dimiliki sehingga ketika menjalani masa-masa perkuliahan banyak di antara mahasiswa yang merasa tidak nyaman dan ini berdampak pada hasil belajar yang diperoleh pun tidak optimal.

Untuk mengembangkan keterampilan ini di perguruan tinggi, mahasiswa dapat mengikuti atau melibatkan diri di dalam kegiatan ekstrakurikuler seperti tergabung dalam salah satu Unit Kegiatan Mahasiswa (UKM) yang ada di kampus. Namun sebelum memilih dan mengikuti salah satu UKM tersebut mahasiswa perlu mengidentifikasi minat dan bakat yang dimilikinya, mahasiswa perlu memahami perbedaan diantara keduanya. Dalam KBBI, bakat diartikan sebagai dasar (kepandaian, sifat, dan pembawaan) yang dibawa sejak lahir. Gardner menyebut bakat sebagai kecerdasan majemuk, menurut Gardner manusia memiliki kecerdasan yang berbeda-beda, diantaranya adalah kecerdasan bahasa (linguistic); kecerdasan logika-matematik (mathematical); kecerdasan musik (musical); kecerdasan kinestetik (kinesthetic); kecerdasan ruang bidang (spatial); kecerdasan interpersonal; kecerdasan intrapersonal; kecerdasan naturalistik; kecerdasan eksistensial. Individu dapat mengidentifikasi sendiri bakat yang dimilikinya melalui proses internalisasi konsep 4E (Easy, Enjoy, Excellent, dan Earn) atau melalui prosedur psikologi tes.

Santosa (2017) memaparkan bahwa sesuatu dapat dikatakan sebagai sebuah bakat bila menunjukkan 4 E dalam pelaksanaannya, yaitu mudah (Easy) dipelajari dan dikuasai oleh 
individu, Enjoy atau dapat dinikmati dalam proses pengembangan dan latihannya, mencapai prestasi terbaik ketika ditampilkan di depan umum (Excellent) dan memberikan manfaat serta dapat dinikmati baik bagi dirinya sendiri ataupun bagi orang lain (Earn). Bila sesuatu hanya dapat dinikmati oleh diri sendiri dan tidak menetap lama maka bisa jadi itu hanyalah minat karena menurut Slameto (1995) minat adalah suatu rasa lebih suka dan rasa keterikatan pada suatu hal atau aktivitas, tanpa ada yang menyuruh. Sedangkan menurut Mohamad Surya (2003: 100) minat dapat diartikan sebagai rasa senang atau tidak senang dalam menghadapi suatu objek.

Berdasarkan pemaparan di atas maka dapat disimpulkan bahwa bakat merupakan kemampuan yang berasal dari hereditas(pembawaan). Cepat atau lambatnya individu dalam menyelesaikan tugas-tugasnya dipengaruhi tingkat intelegensi dan bakatnya. Bakat akan terus ada dalam diri individu, dilatih atautidak kemampuan bakat individu akan bersifat permanen. Sementara minat merupakankemampuan yang berupa kemauan individu yang tinggi terhadap sesuatu yang dipengaruhi oleh lingkungannya.Minat sangat dipengaruhi oleh lingkungan sebab dapat berubah karena perubahan trend maupun perubahan hobby individu tersebut (berorientasi pada hobby). Akan tetapiminat akan berpengaruh besar dalam perkembangan intelegensi dan bakat individukarena dengan memiliki minat akan membangkitkan motivasi individu dalam mengasahkemampuan yang ada pada dirinya.

Indikator selanjutnya yang masih berada pada kategori sedang adalah kemampuan untuk tidak tergoda dengan keuntungan sesaat. Indikator ini merupakan bagian dari keterampilanmenghindari jebakan pilihan. Keterampilan ini bertujuan meminimalisir penyesalan yang mungkin dirasakan oleh individu kerena keliru dalam mengambil sebuah keputusan. Wardani (2010) memaparkan beberapa langkah yang dapat membantu individu menghindari jebakan dalam membuat pilihan yang terkadang dapat menyesatkan dari keinginan yang sesungguhnya hendak dicapai, yaitudengan meneliti lebih dalam suatu pilihan, mampu berpikir jernih dalam kondisi terdesak, tidak tergoda dengan keuntungan sesaat, menghindari prasangka, dan tidak mudah terpengaruh oleh orang lain.

Indikator lainnya yang masih perlu dikembangakan oleh mahasiswa PGSD adalag kemampuan untukmembuat peta pilihan. Indikator ini bagian dari keterampilan memanajemen penentuan pilihan. Wardani (2010) memaparkan bahwa proses memantapkan keinginan yang menggunakan manajemen merupakan suatu cara yang paling efektif dan tidak mengambil resiko yang cukup besar karena disertai dengan penanganan kesalahan dan akibat-akibatnya. Individu perlu mengidentifikasi dengan baik berbagai resiko yang mungkin ditimbulkan dari pilihan-pilihan yang dibuatnya karena keputusan terbaik terletak pada kemampuan meminimalkan resiko dan memprediksi konsekuensi. Keahlian memprediksi tersebut merupakan suatu keahlian yang harus dilatih, diasah dan dipertajam dengan begitu individu akan semakin ahli dalam membuat keputusan yang berkualitas. Oleh sebab itu, individu perlu mempertimbangkan tiga waktu sebelum membuat atau mengambil sebuah keputusan, yaitu saat ini, masa lalu dan masa depan.

\section{SIMPULAN DAN SARAN}

Berdasarkan hasil penelitian yang diperoleh maka dapat disimpulkan bahwa secara umum keterampilan mahasiswa PGSD angkatan 2016-2019 adalah sebagai berikut.

Mayoritas keterampilan pengampilan keputusan mahasiwa PGSD angkatan 2016-2019 telah mencapai kategori yang tinggi meskipun ada beberapa indikator yang masih berada pada kategori sedang, rendah dan rendah sekali. Indikator yang masih berada pada kategori sedang diantaranya adalah indikator yang menunjukkan kemampuan untuk memperhitungkan kemampuan fisik, intelektual dan mental; kemampuan untuk tidak tergoda dengan keuntungan sesaat; kemampuan untuk memperhitungkan antara minat dan harapan; 
kemampuan untuk mengetahui dampak dari setiap pilihan; dan kemampuan untuk membuat peta pilihan.

Indikator yang masih berada pada kategori rendah dan rendah sekali adalah indikator yang menunjukkan kamampuan untuk menyesuaikan antara keinginan. Indikator-indikator tersebut merupakan bagian dari keterampilan menghitung segala aspek pilihan dan keterampilan menghindari jebakan pilihan. Sehingga dibutuhkan sebuah program rencana bantuan pengembangan keterampilan pengambilan keputusan yang diarahkan pada dua keterampilan tersebut. 
Myrna Apriany Lestari

TINGKAT KETERAMPILAN PENGAMBILAN KEPUTUSAN MAHASISWA PENDIDIKAN

GURU SEKOLAH DASAR UNIVERSITAS KUNINGAN

\section{DAFTAR PUSTAKA}

Santosa, Hari. (2017). Buku fitrah based education, mengembalikan pendidikan sejati selaras fitrah, misi hidup dan tujuan hidup. Yayasan Cahaya Mutiara Timur.

Slameto. (1995). Belajar dan faktor-faktor yang mempengaruhinya. Jakarta: Rineka Cipta.

Muhamad Surya. (2003). Psikologi pembelajaran dan pengajaran. Jakarta: Mahaputra Adidaya

Wardani, Dani. (2010). 7 langkah membuat keputusan terbaik. Yogyakarta: Leutika. 